\title{
Enhanced production of thermostable lipase from Bacillus cereus ASSCRC-P1 in waste frying oil based medium using statistical experimental design
}

\author{
Ghada E. A. Awad ${ }^{1}$, Hanan Mostafa $^{1}$, Enas N. Danial ${ }^{1}$, Nayera A.M. Abdelwahed ${ }^{1}$, Hassan M. Awad ${ }^{1 *}$ \\ ${ }^{1}$ Chemistry of Natural and Microbial Products Dept., Pharmaceutical Industries Div., National Research Centre, 33 El Buhouth St.( Former El Tahrir St.), \\ 12622-Dokki, Giza, Egypt.
}

\section{ARTICLE INFO \\ Article history: \\ Received on: 23/05/2015 \\ Revised on: 06/06/2015 \\ Accepted on: 21/07/2015 \\ Available online: 27/09/2015}

\section{Key words :}

Isolation and genotypic

identification; Thermostable

lipase; Waste frying

sunflower oil; Bacillus

cereus ASSCRC-P1;

Statistical designs.

\begin{abstract}
This study aim to isolate, identify a bacterial isolate and optimize production medium using frying oil waste for lipase production. Nine strains were isolated from an Egyptian soil samples. Among the isolates, a potent bacterial candidate ASSCRC-P1 was found to be the most potent lipase producer strain at $60{ }^{\circ} \mathrm{C}$. Genotypic identification of ASSCRC-P1 showed 94\% similarity with Bacillus sp. strains. Phylogenetic tree confirmed that ASSCRC-P1 was nearly similar to Bacillus cereus. Therefore, it was given the name Bacillus cereus ASSCRCP1 and its 16S rRNA nucleotide has been deposited in the GenBank Data Library under the accession number: KJ531440. A sequential optimization strategy, based on statistical experimental designs, was employed to enhance the lipase production by this strain. A 2-level Plackett-Burman design was applied to differentiate between the bioprocess parameters that significantly influence lipase production followed by Box-Behnken design to optimize the amounts of variables which have the highest positive significant effect on lipase production. Overall more than 2.15-fold improvement in lipase production was achieved due to optimization compared to that obtained using the basal medium.
\end{abstract}

\section{INTRODUCTION}

Lipases (triacylglycerol acylhydrolases; EC 3.1.1.3) are widely distributed among microorganisms, animals and plants and they catalyze the hydrolysis of esters of long chain aliphatic acids from glycerol at lipid and water interfaces (Jensen 1983). Lipases are produced by several microorganisms, viz., bacteria, fungi, yeast, actinomycetes, archea, eucarya, etc. Microbial genera involved in the commercial production of lipases include: Candida, Mucor, Rhizopus, Aspergillus, Penicillium, Geotrichum, Rhizomucor, Bacillus, Pseudomonas and Staphylococcus (Aravindan et al., 2007). Microorganisms with potentials for producing lipases can be found in different habitats, including wastes of vegetable oils and dairy industries, soils contaminated with oils, seeds, and deteriorated food (Sharma et al., 2001). Only microbial thermostable lipases are

\footnotetext{
* Corresponding Author

Email: awadmhassan@yahoo.com
}

commercially significant for their potential use in industries, such as speciality organic syntheses (Rubin and Dennis 1997), hydrolysis of fats and oils, modification of fats, flavor enhancement in food processing (Kazlauskas and Bornscheuer 1998), resolution of racemic mixtures and chemical analyses (Lee et al., 1995). A major requirement for thermally stable lipase would allow enzymatic reaction to be performed at higher temperatures and would be helpful to increase conversion rates, substrate solubility and to reduce the contamination of microorganism. Several lipases have been purified and characterized from thermophilic isolates, mainly from Bacillus (Kumar et al., 2014). Fried food is a major component of diets in many countries. The increasing demand for fried food has resulted in large quantities of waste frying oil. Kock et al. (1996) reported that used frying oils contained more than $30 \%$ of polar compounds from the oxidative degradation of triglycerides.

These oils can be considered a high-energy food source, till now used/discharged for animal feed, but they also may be considered as high-energy source for microbial growth and transformation into high-value products (Haba et al., 2000). 
Generally, high productivity has been achieved by culture medium optimization. Optimization of the concentration of each compound that constitutes cultivation medium is usually a time-consuming procedure.

The use of by-products as substrates for lipase production, adds high value and low-cost substrates may reduce the final cost of the enzyme (Veerapagu et al., 2013). Statistical optimization using Response Surface Methodology (RSM) has been widely used to augment the conventional shake flask method especially when a large number of variables are to be evaluated. It has helped to determine the optimum concentration of selected media components (Sunitha et al., 1998). Optimization of lipase production by RSM has been reported in cultures of Cadida sp., Pseudomonas aeruginosa and Bacillus pumillus (Chien-Hung et al., 2006).

The main objective of the present study was to isolate and genotypically identify bacterial strain that efficiently expresses a desirable thermostable lipase. RSM optimization methods were implemented to maximize the enzyme production by using waste frying sunflower oil.

\section{MATERIALS AND METHODS}

\section{Sample collection and isolation of thermostable lipase producing bacteria}

Soil samples were collected during summer from soil contaminated with oil beside the oil wells in El Ain El Sokhna, open lagoons area in Ras Sedr and from soil around Mosa spring in South Sinai. Soil samples are collected in sterile containers and store in refrigerator at $4{ }^{\circ} \mathrm{C}$ until reached to the laboratory. Isolation of thermophilic bacteria with lipolytic activity was carried out according to the method adopted by Gowland et al. (1987). In situ, enrichment was achieved by mixing the soil samples with sterile commercial cocking oil and incubating for 10 days at $65^{\circ} \mathrm{C}$. Enriched soil samples were suspended in sterile water in a ratio of 1:1. Sequential enrichment of thermophilic bacteria with lipolytic activity was performed by inoculating $1 \mathrm{ml}$ of the soil suspension in a medium consisted of $0.025 \%$ yeast extract and $0.1 \%$ waste cooking sunflower oil emulsified in aqueous $10 \%(\mathrm{w} / \mathrm{v})$ gum Arabic (Abdel Fattah 2008). The inoculated flasks were incubated with shaking at $55^{\circ} \mathrm{C}$. One milliliter of the culture was plated onto agar plates of the same medium for further purification. The single colonies were selected and inoculated in nutrient agar (NA) slants. Bacterial isolates were routinely grown on (NA) medium at $55^{\circ} \mathrm{C}$ and preserved at $-80^{\circ} \mathrm{C}$ in $50 \%$ glycerol.

\section{Identification of thermophilic lipase producing bacteria DNA isolation and PCR amplification}

An overnight culture of the promised bacteria grown at $55^{\circ} \mathrm{C}$ was used for the preparation of genomic DNA. The DNA was isolated using Promega kit for preparation of genomic DNA according to the manufacturer's instructions. PCR amplification of $16 \mathrm{~S}$ rDNA region was carried out according to Sambrook et al. (1989). The $16 \mathrm{~S}$ rDNA was amplified by polymerase chain reaction (PCR) using primers designed to amplify $1500 \mathrm{bp}$ fragment of the $16 \mathrm{~S}$ rDNA region. The domain bacteria-specific primer 27F (forward primer) was 5'AGAGTTTGATCMTGGCTCAG3' and universal bacterial primer 1492R (reverse primer) was 5'TACGGYTACCTTGTTACGACTT3' (Edwards et al., 1989).

The PCR mixture consists of 30 picomoles of each primer, $10 \mathrm{ng}$ of chromosomal DNA, $200 \mu \mathrm{M}$ dNTPs and 2.5 Units of Taq polymerase in $50 \mu \mathrm{l}$ of polymerase buffer. The PCR was carried out for 30 cycles in $94{ }^{\circ} \mathrm{C}$ for $1 \mathrm{~min}, 55^{\circ} \mathrm{C}$ for $1 \mathrm{~min}$ and $72{ }^{\circ} \mathrm{C}$ for 2 minutes. After completion, a fraction of the PCR mixture was examined using agarose gel electrophoresis and the remnant was purified using QIAquick PCR purification reagents (Qiagen).

\section{DNA sequencing, phylogenic analysis and tree construction}

DNA sequences were obtained using 3130 X DNA Sequencer (Genetic Analyzer, Applied Biosystems, Hitachi, Japan), BigDye Terminator Cycle Sequencing. The PCR product was sequenced using the same PCR primers. Automated DNA sequencing based on enzymatic chain terminator technique was done using 3130 X DNA Sequencer (Genetic Analyzer, Applied Biosystems, Hitachi, Japan).

The thermal cycling mixture was as follows: $8 \mu \mathrm{l}$ of BigDye terminator mix, $6 \mu \mathrm{l}$ of the sequencing primer $(10 \mathrm{pmol})$ and $6 \mu \mathrm{l}$ of the sample (PCR product) then the reaction was run in the thermal cycler. The cyclic reaction composed of $1 \mathrm{~min}$ at 95 ${ }^{\circ} \mathrm{C}$, then 49 cycles of $30 \mathrm{sec}$ at $95{ }^{\circ} \mathrm{C}, 10 \mathrm{sec}$ at $52{ }^{\circ} \mathrm{C}$ and $4 \mathrm{~min}$ at $60{ }^{\circ} \mathrm{C}$. The products were purified using special column according to the instruction of the manufacturer. The elute were taken and (1:1) volume ratio of high dye formamide was added and run at 95 ${ }^{\circ} \mathrm{C}$ for $5 \mathrm{~min}$ for denaturation, then shock on ice. Afterward, the samples become ready for sequencing in 3130 X DNA sequencer and analysis

Phylogenetic data were obtained by aligning the nucleotides of different $16 \mathrm{~S}$ RNA retrieved from BLAST algorithm (www.ncbi.nlm.nih.gov/BLAST), using the CLUSTAL $\mathrm{W}$ program version 1.8 with standard parameters. The classifier is trained on the new phylogenetically consistent higher-order bacterial taxonomy (Ribosomal Database Project, RDP Classifier) proposed by Wang et al. (2007), (http://rdp.cme.msu.edu/classifier/classifier.jsp). Phylogenetic and molecular evolutionary analyses were conducted using BioEdit version 7.0.4.01. A rooted phylogram was derived from the distance matrices using the neighbour-joining method through the TREEVIEW program. All analyses were performed on a bootstrapped data set containing 1000 replicates (generated by the program).

\section{Nucleotide sequence ID}

The nucleotide sequence of the $16 \mathrm{~S}$ rRNA gene of strain ASSCRC-P1 has been deposited in the GenBank under accession number: KJ531440. 


\section{Secondary structure prediction and restriction site analysis}

The RNA secondary structure of the isolate ASSCRC-P1 was predicted according to Brodsky et al. (1995) using Genebee online software by the greedy method and the restriction sites of the strain DNA was analyzed by NEB cutter Version 2.0 according to Vincze et al. (2003).

\section{Production of thermophilic lipase}

Production of lipase was carried out using medium consisted of ( $\mathrm{g} \%)$ : Peptone, $0.3 ; \mathrm{KH}_{2} \mathrm{PO}_{4}, 0.2 ; \mathrm{KCl}, 0.05$; $\mathrm{MgSO}_{4} \cdot 7 \mathrm{H}_{2} \mathrm{O}$, glucose, 1.0 and waste frying sunflower oil (WFO) 1.0). The $\mathrm{pH}$ of the medium was adjusted to 7.0 (Akhtar et al., 1980). Cultivation was carried out in $250 \mathrm{ml}$ Erlenmeyer flasks containing $50 \mathrm{ml}$ of production medium . The sterilized flasks were inoculated with $2 \mathrm{ml}$ of $24 \mathrm{~h}$ old inoculum. The optical density of the inoculum was adjusted to 1.0 at $600 \mathrm{~nm}$. The inoculated flasks were incubated at $45^{\circ} \mathrm{C}$ for $72 \mathrm{~h}$ in a rotary shaker adjusted at 200 rpm.

\section{Determination of the lipase enzyme activity}

Samples were analyzed according to Huge-Jensen et al. (1987). One $\mathrm{ml}$ of culture filtrate was mixed with $2.5 \mathrm{ml}$ of deionized water and $1 \mathrm{~mL}$ of $0.1 \mathrm{M}$ of tris $-\mathrm{HCl}$ buffer $(\mathrm{pH} 7.5), 3$ $\mathrm{ml}$ of $10 \%(\mathrm{v} / \mathrm{v})$ triglyceride emulsion $(10 \%(\mathrm{v} / \mathrm{v})$ of the triglycerides (tributyrin or olive oil) emulsified in $10 \%(\mathrm{w} / \mathrm{v})$ Arabic gum in a hot water and homogenized in a top drive homogenizer for $10 \mathrm{~min}$ ). The mixture was incubated for $2 \mathrm{~h}$ at 37 ${ }^{\circ} \mathrm{C}$ in a shaking water bath. At the end of incubation time $10 \mathrm{ml}$ of 99\% ethyl alcohol was added and the resulting mixture was then titrated against $0.05 \mathrm{~N} \mathrm{NaOH}$ using thymolphthalein as indicator, boiled enzyme samples were used as blank. One unit of lipase activity was defined as the amount of enzyme that produced 1 $\mu$ mole of free fatty acids per min under the standard assayed conditions. The activities were expressed in $\mathrm{U} / \mathrm{ml}$.

\section{Thermal stability of the lipase producing bacteria}

Crude lipase enzyme produced by bacterial isolate coded GP1(ASSCRC-P1) was tested for its thermal stability by incubating the crude enzyme solution for 240 minutes in water baths adjusted to $60^{\circ} \mathrm{C}$ and $65^{\circ} \mathrm{C}$ (Kumar et al., 2005). Samples were taken each 30 minute for lipase activity determination.

\section{Experimental designs}

\section{Plackett-Burman design}

The Plackett-Burman experimental design was used to evaluate the relative importance of various nutrients for the production of lipase by Bacillus cereus ASSCRC-P1 in submerged fermentation. Fifteen components were selected and each variable was represented at two levels, high concentration $(+1)$ and low concentration (-1) in 16 trials as shown in Table 1 (Plackett and Burman, 1946). The tested factors included culture volume, waste frying oil, Tween 80, Triton $\mathrm{X}-100$, peptone, beef extract, $\mathrm{K}_{2} \mathrm{HPO}_{4}, \mathrm{KH}_{2} \mathrm{PO}_{4}, \mathrm{NaCl}, \mathrm{KCl}, \mathrm{FeSO}_{4}, \mathrm{ZnSO}_{4}, \mathrm{MgSO}_{4}, \mathrm{CuSO}_{4}$, and
$\mathrm{MnSO}_{4}$. Each row represents a trial run and each column represents an independent variable.

Plackett Burman experimental design is based on the first order model:

$\mathrm{Y}=B_{0}+\Sigma B_{i} x_{i}$. Eq. (1) Where $\mathrm{Y}$ is the response (lipase activity), $B_{0}$ is the model intercept and $B_{i}$ is the variables estimates. The effect of each variable was determined by following equation, $\mathrm{E}\left(X_{\mathrm{i}}\right)=2\left(\boldsymbol{\Sigma} \mathrm{M}_{\mathrm{i}}^{+}-\mathrm{M}_{\mathrm{i}}{ }^{-}\right) / \mathrm{N}$. $\quad$ Eq. (2)

Where $E\left(X_{i}\right)$ is the effect of the tested variable, $M_{i}{ }^{+}$and $M_{i}^{-}$represent lipase production from the trials where the variable $\left(X_{i}\right)$ measured was present at high and low concentrations, respectively and $N$ is the number of trials in Eq. (2).

The standard error (SE) of the concentration effect was the square root of the variance of an effect and the significance level ( $p$ value) of each concentration effect was determined using student's $t$-test

$t\left(X_{i}\right)=\mathrm{E}\left(X_{i}\right) / \mathrm{SE} \ldots \ldots$ Eq. (3) Where $\mathrm{E}\left(X_{i}\right)$ is the effect of variable $X_{\mathrm{i}}$.

\section{Box-Behnken design}

In order to describe the nature of response surface in the experimental region, a Box-Behnken design was applied (Box and Behnken 1960). As presented in (Table 2), three favorable salts were prescribed into three levels, coded $-1,0$ and +1 for low, middle and high concentrations (or values) respectively.

The results in Table 2 represent the design matrix of a 15 trial experiment. For predicting the optimal point, a second order polynomial function was fitted to correlate relationship between independent variables and response lipase production. For the three factors the polynomial equation is in the following form:

$\mathrm{Y}=\beta_{0}+\beta_{1} \mathrm{x}_{1}+\beta_{2} \mathrm{x}_{2}+\beta_{3} \mathrm{x}_{3}+\beta_{11} \mathrm{x}_{1}{ }^{2}+\beta_{22} \mathrm{x}_{2}{ }^{2}+\beta_{33} \mathrm{x}_{3}{ }^{2}+\beta \mathrm{b}_{12} \mathrm{x}_{1} \mathrm{x}_{2}+$ $\beta_{13} \mathrm{x}_{1} \mathrm{x}_{3}+\beta_{23} \mathrm{x}_{2} \mathrm{x}_{3}$ Eq.(4)

Where $\mathrm{Y}$ is the predicted production of lipase $(\mathrm{U} / \mathrm{ml}), \mathrm{X}_{1}, \mathrm{X}_{2}$ and $\mathrm{X}_{3}$ are the independent variables corresponding to the concentration of waste frying oil, triton X-100 and $\mathrm{MnSO}_{4}$ respectively; $\beta_{0}$ is the intercept, $\beta_{1}, \beta_{2}, \beta_{3}$ are linear coefficients, $\beta_{11}, \beta_{22}, \beta_{33}$ are quadratic coefficients, $\beta_{12}, \beta_{13}, \beta_{23}$ are cross product coefficients. Statistical software SPSS (version 16.0) was used for the regression analysis of the experimental data obtained. The quality of fit of the polynomial model equation was expressed by the coefficient of determination $R^{2}$. Experiments were performed in triplicate and mean values are given.

\section{RESULTS AND DISCUSSION}

\section{Screening of different bacterial isolates for production of lipase enzyme}

When the effluent samples were serially diluted and plated in a nutrient medium that enriched lipolytic organisms, nine bacterial strains were isolated as described in experimental part and cultivated in the production medium. All bacterial isolates produce a considerable amount of lipase enzyme but highest lipase activity $(160 \mathrm{U} / \mathrm{ml})$ was achieved by bacterial isolate coded GP1 (ASSCRC-P1) (Figure 1). These results were more than that 
obtained from several researchers as Guzman and Virginia (2008) who detected lypolytic activity of $0.079 \mathrm{U} / \mathrm{ml}$ by Bacillus pumilus LV01 isolated from water samples and maximum lipase production of $12 \mathrm{U} / \mathrm{ml}$ by Pseudomonas gessardii selected from a soil sample (Veerapagu et al., 2013). These results were in accordance to Boonmahome and Mongkolthanaruk (2013) who found that Pseudomonas aeruginosa isolate NA37 selected from soil contaminated with oil in Khon Kaen region showed high lipase activity $(190 \mathrm{mU} / \mathrm{ml})$ detecting with $p$-nitrophenyl palmitate as a substrate. On the other hand, Dhiman and Chapadgaonkar (2013) isolated and identified as Bacillus ISC 1, from a site of regular oil spill, showed high lipase production of $25 \mathrm{U} / \mathrm{ml}$.

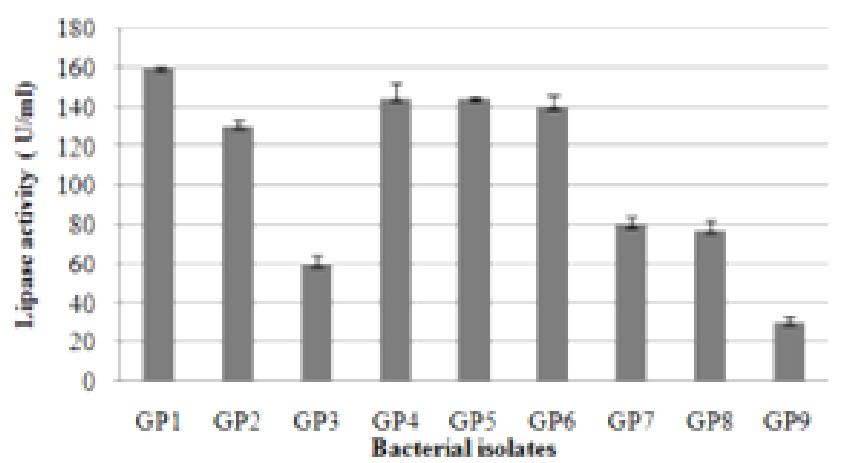

Fig. 1: Screening of bacterial isolates for their ability to produce lipase enzyme

Identification and taxonomic classification of bacterial isolate ASSCRC-P1

The primer specificity, sequencing and phylogenetic analysis

The primer pairs' 27F/1492R amplified the fragments of the expected size (around 1400-1500 in the gel) of the genomic DNA isolated from strain ASSCRC-P1. The amplification capacity of this primer is $27 \mathrm{bp}$ and $1492 \mathrm{bp}$ fragments and the nucleotides ranged between 8 to $1507 \mathrm{bp}$. The 16S rRNA gene amplified with a set of universal primers $27 \mathrm{~F}$ and $1492 \mathrm{R}$ from ASSCRC-P1 isolate was observed on agarose gel electrophoresis.

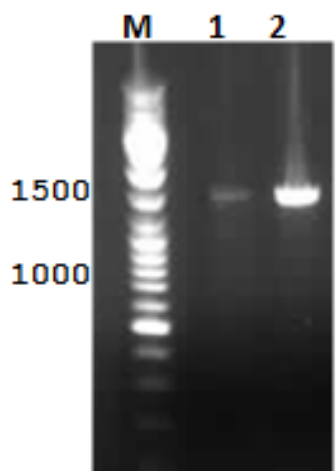

Fig. 2: Agarose gel electrophoresis of PCR products obtained by amplification from genomic DNA isolated from Bacillus strains with the primer pairs. Lane 1 M: molecular-weight marker; Lane 2, purified PCR product; Lane 3, PCR product for 16s rDNA (1500bp) of Bacillus cereus ASSCRC-P1.

The results in Fig. 2 showed an amplicon band with the size of about $1.5 \mathrm{~kb}$. These results were in accordance with that reported by Akhmaloka et al. (2006) who found that the PCR products using primers $27 \mathrm{~F}$ and $1492 \mathrm{R}$ should be about 1500 base pairs long. The specificity of the PCR is affected by multiple factors, especially the primer pairs. In this study, the $27 \mathrm{~F} / 1492 \mathrm{R}$ primer pair was used as a specific primer for bacteria. The primer was examined by PCR amplification using genomic DNA, isolated from strain ASSCRC-P1. The primers were successfully used to amplify genomic DNA from the isolated sample. These results are in agreement with those cited by Edwards et al. (1989) who found that these primers are specific for bacteria.

\section{Alignment, phylogenetic tree construction and $\mathbf{G}+\mathbf{C} \%$}

The nucleotide sequence of Bacillus cereus ASSCRC-P1 strain was matched with the $16 \mathrm{~S}$ rRNA reported gene sequences in the gene bank database. The database of NCBI Blast (www.ncbi.nlm.nih.gov/BLAST) was used to compare the Bacillus cereus ASSCRC-P1 with those of Bacillus species strains. The results showed the high sequence similarity species $(94 \%)$ with Bacillus pumilus and Bacillus cereus strains.

The phylogenetic tree of the strain (Figure 3) showed that strain ASSCRC-P1 is most closely related to Bacillus cereus. Therefore, it was proposed a name Bacillus cereus ASSCRC-P1. The nucleotide sequence of $16 \mathrm{~S}$ rRNA gene has been deposited in GenBank under accession number: KJ531440.

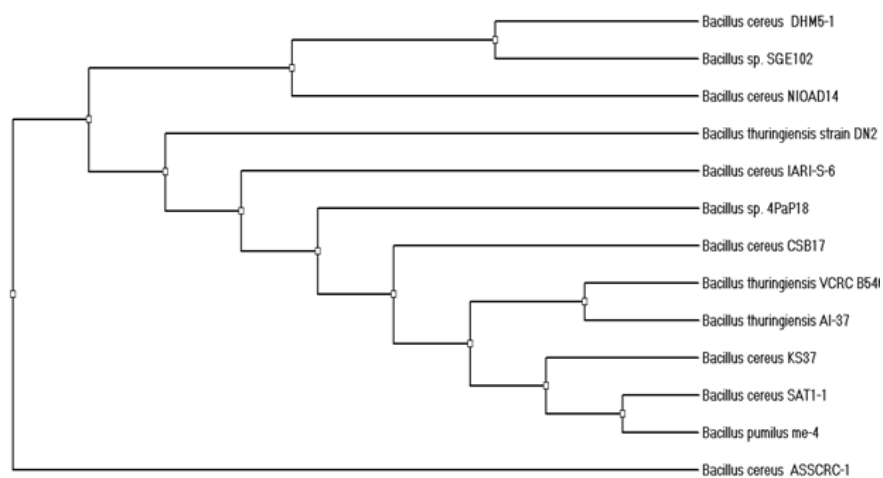

Fig. 3: Neighbor-joining phylogenetic representation of the strains and their closest NCBI (BLAST) relatives based on 16S rRNA gene sequences of $B$. cereus ASSCRC-P1and some known sequences of B. cereus $\mathrm{sp}$.

The percentage of $\mathrm{G}+\mathrm{C}$ is one of many general features used to characterize bacterial genomes. The $\mathrm{G}+\mathrm{C}$ content of the genomic DNA was 54 mol\% obtained from the phylogenetic analysis. These results were in accordance to that reported by Galtier and Lobry (1997); McCutcheon and Moran (2010) who mentioned the percentage composition of the known Bacillus species can range from $25 \%$ to $75 \%$ for $\mathrm{G}+\mathrm{C}$ richness.

\section{Secondary structure prediction and restriction site analysis}

The RNA secondary structure was predicted for $16 \mathrm{~S}$ rRNA of Bacillus cereus ASSCRC-P1 (Figure 4). It showed that the free energy of structure is $-24.4 \mathrm{kkal} / \mathrm{mol}$, threshold energy is 4.0 with cluster factor, conserved factor 2 , compensated factor 4 and conservatively is 0.8 . The prediction of restriction sites of Bacillus cereus ASSCRC-P1 strain showed the restriction sites for 
various enzymes such as Bfal, Spel, EcoP151, EcoR 1, BSPMI and Bsgl etc (Figure 5).

Free Energy of structure $=-24.4 \mathrm{kkal} / \mathrm{mol}$

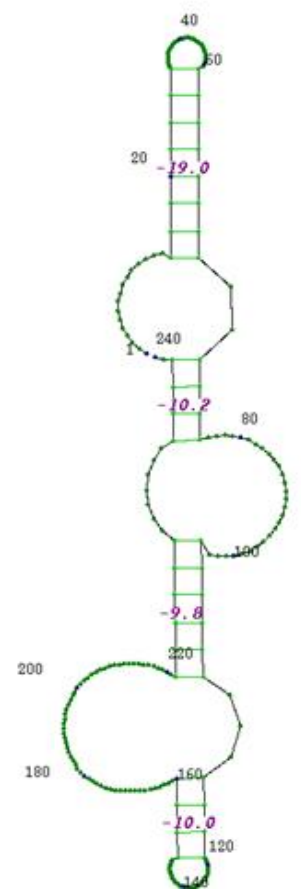

Fig. 4: Secondary structure prediction of 16s rRNA of the strain Bacillus cereus ASSCRC-P1 was done using Genebee online software

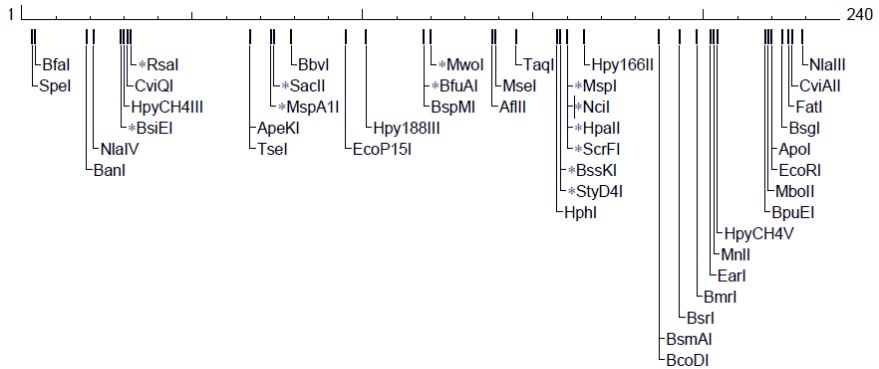

Fig. 5: Restriction sites of the strain Bacillus cereus ASSCRC-P1 were predicted using NEB single cutter

\section{Thermal stability of the Bacillus cereus ASSCRC-P1 lipase}

For achieving our goal, we tested the thermal stability of lipase produced by bacterial isolate GP1 (ASSCRC-P1) by incubating the crude enzyme solution for 240 minutes in water baths adjusted to 60 and $65^{\circ} \mathrm{C}$. Figure 6 showed that the lipase enzyme can stand up to $180 \mathrm{~min}$ at $60^{\circ} \mathrm{C}$ and lost only $10 \%$ of its activity after 210 min while the enzyme can stand at $65^{\circ} \mathrm{C}$ for about $150 \mathrm{~min}$ and its activity retain $100 \%$ with slight loss of its activity with the increase of incubation time at the same temperature. The stability of the lipase at high temperatures suggests its usefulness in industrial uses as detergents and treatment of domestic sewage employed at temperatures exceeding $50{ }^{\circ} \mathrm{C}$ (Sharma et al., 2002). Similar results were reported by Kumar et al. (2005). Recently several thermostable lipases have been reported from the genus Bacillus such as Bacillus cereus (Senthilkumar and Selvakumar 2007), Bacillus thermoleovorans
(Castro-Ochoa et al., 2005). The bacterial isolate ASSCRC-P1 was chosen for further investigations.

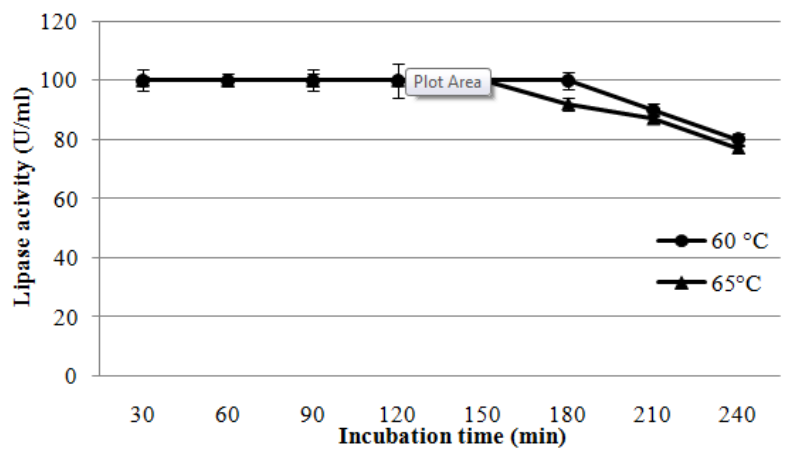

Fig. 6: Thermal stability of Bacillus cereus ASSCRC-P1 lipase activity at $60^{\circ}$ $\mathrm{C}$ and $65^{\circ} \mathrm{C}$

\section{Optimization of lipase production by Bacillus cereus ASSCRC- P1}

The production optimization of lipase was done by two steps

\section{Evaluation of the factors affecting lipase activity by the Plackett-Burman Design}

In the first approach, the Plackett-Burman design was used. Fifteen factors (variables) including culture conditions and medium constitution were chosen to perform this optimization process. The lipase activity averages for the different trials were given in $\mathrm{U} / \mathrm{ml}$ and shown in Table 1 . The main effect of each variable upon lipase activity was estimated as the difference between both measurements averages made at the high level $(+1)$ and at the low level (-1) of that factor. Data in Table 1 showed a wide variation from $18 \pm 1.16$ to $192 \pm 2.677 \mathrm{U} / \mathrm{ml}$ on lipase activity reflected the importance of medium optimization to attain higher yields. Data analysis of the Plackett-Burman experiments involved a first order model. The main effects of the examined factors on the enzyme activity and their ranking were calculated and presented graphically in Figure 7.

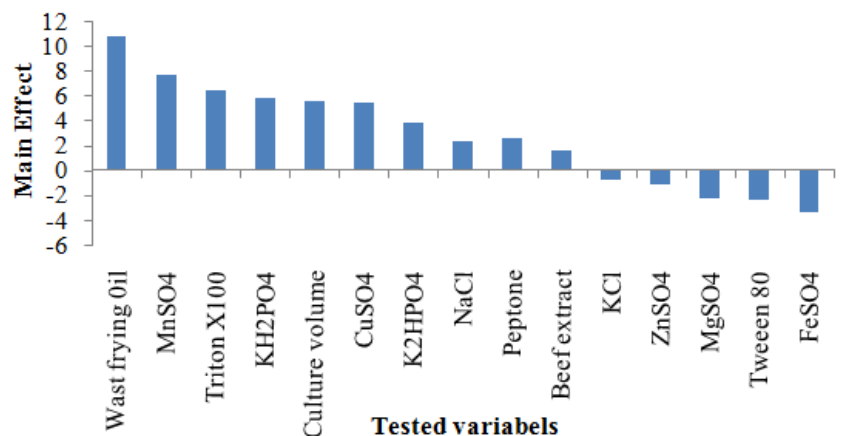

Fig. 7: Effect of different medium composition on lipase activity (U/ml) produced by B. cereus ASSCRC-P1

On the analysis of the regression coefficients of the tested variables: waste frying oil, $\mathrm{MnSO}_{4}$, triton $\mathrm{X}-100, \mathrm{KH}_{2} \mathrm{PO}_{4}$, culture volume, $\mathrm{CuSO}_{4}, \mathrm{~K}_{2} \mathrm{HPO}_{4}, \mathrm{NaCl}$, peptone and beef extract, showed positive effect on lipase activity while $\mathrm{FeSO}_{4}$, Tween 80, 
Table 1: Coded levels and real values for Plackett-Burman experimental design.

\begin{tabular}{|c|c|c|c|c|c|c|c|c|c|c|c|c|c|c|c|c|}
\hline $\begin{array}{l}\text { Trial } \\
\text { No. }\end{array}$ & $X_{1}$ & $X_{2}$ & $X_{3}$ & $X_{4}$ & $X_{5}$ & $X_{6}$ & $X_{7}$ & $X_{8}$ & $X_{9}$ & $X_{10}$ & $X_{11}$ & $X_{12}$ & $X_{13}$ & $X_{14}$ & $X_{15}$ & $\begin{array}{c}\text { Lipase activity } \\
(\mathrm{U} / \mathrm{ml})\end{array}$ \\
\hline & $\begin{array}{l}\text { Culture } \\
\text { Volume }\end{array}$ & $\begin{array}{c}\text { Waste } \\
\text { Frying oil }\end{array}$ & $\begin{array}{c}\text { Tween } \\
80\end{array}$ & $\begin{array}{l}\text { Triton } \\
\text { X100 }\end{array}$ & Peptone & $\begin{array}{c}\text { Beef } \\
\text { extract }\end{array}$ & $\mathrm{K}_{2} \mathrm{HPO}_{4}$ & $\mathrm{KH}_{2} \mathrm{PO}_{4}$ & $\mathrm{NaCl}$ & KCl & $\mathrm{FeSO}_{4}$ & $\mathrm{ZnSO}_{4}$ & $\mathrm{MgSO}_{4}$ & $\mathrm{MnSO}_{4}$ & $\mathrm{CuSO}_{4}$ & \\
\hline 1 & $+1(50)$ & $-1(40)$ & $+1(0.50)$ & $+1(0.5)$ & $-1(5)$ & $+1(10)$ & $-1(1)$ & $-1(1)$ & $+1(0.5)$ & $+1(0.5)$ & $+1(0.001)$ & $-1(0)$ & $+1(0.001)$ & $-1(0)$ & $+1(0.001)$ & $34.80 \pm 0.669$ \\
\hline 2 & $-1(25)$ & $+1(80)$ & $+1(0.50)$ & $-1(0.25)$ & $-1(5)$ & $-1(5)$ & $-1(1)$ & $+1(2)$ & $+1(0.5)$ & $+1(0.5)$ & $-1(0)$ & $+1(0.001)$ & $-1(0)$ & $+1(0.001)$ & $-1(0)$ & $82.86 \pm 3.701$ \\
\hline 3 & $+1(50)$ & $+1(80)$ & $-1(0.25)$ & $+1(0.5)$ & $-1(5)$ & $-1(5)$ & $+1(2)$ & $-1(1)$ & $+1(0.5)$ & $-1(0)$ & $+1(0.001)$ & $-1(0)$ & $+1(0.001)$ & $+1(0.001)$ & $+1(0.001)$ & $125.52 \pm 5.63$ \\
\hline 4 & $-1(25)$ & $-1(40)$ & $+1(0.5)$ & $+1(0.5)$ & $+1(10)$ & $-1(5)$ & $+1(2)$ & $+1(2)$ & $-1(0)$ & $+1(0.5)$ & $-1(0)$ & $+1(0.001)$ & $-1(0)$ & $+1(0.001)$ & $+1(0.001)$ & $125.52 \pm 1.378$ \\
\hline 5 & $-1(25)$ & $+1(80)$ & $-1(0.25)$ & $-1(0.25)$ & $+1(10)$ & $+1(10)$ & $+1(2)$ & $+1(2)$ & $+1(0.5)$ & $-1(0)$ & $+1(0.001)$ & $-1(0)$ & $+1(0.001)$ & $-1(0)$ & $-1(0)$ & $85.50 \pm 6.1000$ \\
\hline 6 & $-1(25)$ & $-1(40)$ & $-1(0.25)$ & $+1(0.5)$ & $+1(10)$ & $+1(10)$ & $-1(1)$ & $-1(1)$ & $-1(0)$ & $+1(0.5)$ & $-1(0)$ & $+1(0.001)$ & $+1(0.001)$ & $+1(0.001)$ & $+1(0.001)$ & $060.00 \pm 5.118$ \\
\hline 7 & $+1(50)$ & $-1(40)$ & $-1(0.25)$ & $-1(0.25)$ & $-1(5)$ & $+1(10)$ & $+1(2)$ & $+1(2)$ & $+1(0.5)$ & $-1(0)$ & $+1(0.001)$ & $+1(0.001)$ & $-1(0)$ & $-1(0)$ & $-1(0)$ & $078.42 \pm 2.165$ \\
\hline 8 & $+1(50)$ & $-1(40)$ & $+1(0.50)$ & $-1(0.25)$ & $+1(10)$ & $-1(5)$ & $-1(1)$ & $-1(1)$ & $-1(0)$ & $+1(0.5)$ & $+1(0.001)$ & $-1(0)$ & $+1(0.001)$ & $+1(0.001)$ & $-1(0)$ & $065.28 \pm 1.575$ \\
\hline 9 & $+1(50)$ & $+1(80)$ & $+1(0.50)$ & $-1(0.25)$ & $-1(5)$ & $+1(10)$ & $+1(2)$ & $-1(1)$ & $+1(0.5)$ & $+1(0.5)$ & $-1(0)$ & $+1(0.001)$ & $-1(0)$ & $-1(0)$ & $-1(0)$ & $124.86 \pm 0.512$ \\
\hline 10 & $-1(25)$ & $+1(80)$ & $+1(0.50)$ & $+1(0.5)$ & $+1(10)$ & $-1(5)$ & $-1(1)$ & $-1(1)$ & $+1(0.5)$ & $-1(0)$ & $+1(0.001)$ & $-1(0)$ & $-1(0)$ & $+1(0.001)$ & $+1(0.001)$ & $151.08 \pm 4.685$ \\
\hline 11 & $+1(50)$ & $+1(80)$ & $-1(0.25)$ & $+1(0.5)$ & $-1(5)$ & $+1(10)$ & $+1(2)$ & $+1(2)$ & $-1(0)$ & $+1(0.5)$ & $-1(0)$ & $-1(0)$ & $-1(0)$ & $+1(0.001)$ & $+1(0.001)$ & $192.00 \pm 2.677$ \\
\hline 12 & $-1(25)$ & $-1(40)$ & $+1(0.50)$ & $-1(0.25)$ & $+1(10)$ & $-1(5)$ & $+1(2)$ & $+1(2)$ & $+1(0.5)$ & $-1(0)$ & $-1(0)$ & $-1(0)$ & $+1(0.001)$ & $-1(0)$ & $-1(0)$ & $110.22 \pm 1.850$ \\
\hline 13 & $+1(50)$ & $+1(80)$ & $-1(0.25)$ & $+1(0.5)$ & $+1(10)$ & $+1(10)$ & $-1(1)$ & $+1(2)$ & $-1(0)$ & $-1(0)$ & $-1(0)$ & $+1(0.001)$ & $+1(0.001)$ & $+1(0.001)$ & $+1(0.001)$ & $168.00 \pm 2.047$ \\
\hline 14 & $-1(25)$ & $-1(40)$ & $+1(0.50)$ & $-1(0.25)$ & $-1(5)$ & $+1(10)$ & $+1(2)$ & $-1(1)$ & $-1(0)$ & $-1(0)$ & $+1(0.001)$ & $+1(0.001)$ & $+1(0.001)$ & $-1(0)$ & $-1(0)$ & $036.00 \pm 2.402$ \\
\hline 15 & $+1(50)$ & $+1(80)$ & $1(60)-$ & $+1(0.5)$ & $+1(10)$ & $-1(5)$ & $-1(1)$ & $+1(2)$ & $-1(0)$ & $+1(0.5)$ & $+1(0.001)$ & $+1(0.001)$ & $-1(0)$ & $-1(0)$ & $+1(0.001)$ & $084.18 \pm 1.457$ \\
\hline 16 & $-1(25)$ & $-1(40)$ & $-1(60)-$ & $-1(0.25)$ & $-1(5)$ & $-1(5)$ & $-1(1)$ & $-1(1)$ & $-1(0)$ & $-1(0)$ & $-1(0)$ & $-1(0)$ & $-1(0)$ & $-1(0)$ & $-1(0)$ & $018.00 \pm 1.160$ \\
\hline
\end{tabular}

Real values (given in parentheses) are in $\mathrm{g}$. 
$\mathrm{MgSO}_{4}, \mathrm{ZnSO}_{4}$ and $\mathrm{KCl}$ were negatively contributed. The first order model describing the correlation between the fifteen factors and the lipase activity could be presented as follows:

$$
\begin{gathered}
\mathrm{Y}_{\text {activity }}=93.488+23.155 X_{I}+12.808 X_{2}+25.930 X_{3}+12.621 X_{4}+ \\
2.559 X_{5}-10.325 X_{6}-16.83 X_{T}-23.087 X_{8}-19.201 X_{9}-2.021 X_{10^{+}} \\
12.343 X_{11}+15.143 X_{12}+11.101 X_{13}+14.449 X_{14}+16.845 X_{15}(\mathrm{Eq} .5) .
\end{gathered}
$$

Based on the calculated $t$-test and $p$-values (Table 3), it was evident that the waste frying oil, triton TritonX-100 and $\mathrm{MnSO}_{4}$ were found to be the most significant variables affecting lipase production. The uses of waste frying oil in production of lipase is involved in the recycling of insoluble organic material (Dandik, et al., 1993) and is also use as alternative substrates for the production of medium or high-value products presents an advantage over the traditional processes. The recycling of materials leads to what has been called "clean technology", in which materials are systematically used and re-used to bring about the drastic increase in resource activity needed to make human activity sustainable (Veerapagu et al., 2013). Lin et al. (1995) found that addition of triton X-100 to the fermentation medium of Pseudomonas pseudoalcaligenes F-111 increased the alkaline lipase production by 50 -fold. Similar results were obtained by Castro-Ochoa et al. (2005) for activating lipase production by Bacillus thermoleovorans CCR11. On the other hand, addition of $\mathrm{MnSO}_{4}$ enhances the production of lipase by Acinetobacter haemolyticus (Clift, 1997).

Other variables with less significant effect were not included in the next optimization experiment, but instead they were used in all trials at their (+1) level, for the positively contributing variables. According to these results, the optimized medium composed of the following in $(\mathrm{g} / \mathrm{l}): \mathrm{KH}_{2} \mathrm{PO}_{4}, 2$; $\mathrm{K}_{2} \mathrm{HPO}_{4}, 2$; peptone, 5; beef extract, 5; $\mathrm{CuSO}_{4}, 0.001 ; \mathrm{NaCl}, 0.5$ was used as a plain medium for further investigations.

\section{Evaluation of the factors affecting lipase activity by Box- Behnken experimental design}

In order to search for the optimum concentration of the most significant medium components, (waste frying oil, triton $\mathrm{X}-100$ and $\mathrm{MnSO}_{4}$ ) showing confidence level $99 \%$ and above in the Plackett-Burman design for lipase production, experiments were performed according to the Box-Behnken design. The results obtained were analyzed by standard analysis of variance (ANOVA) as shown in Table 2. The second-order regression equation provided the levels of lipase production as a function of $\mathrm{X}_{1}, \mathrm{X}_{2}$ and $\mathrm{X}_{3}$ can be predicted by the following equation:

$Y_{\text {lipase }}=-410.548+13.479 X_{1}-109.823 X_{2}+187492.197 X_{3}-$ $0.090 X_{1}^{2}+7.911 X_{2}^{2}-0.0003386 X_{3}^{2}+0.576 X_{1} X_{2}-400.770 X_{I} X$

$$
3-410.548 X_{2} X_{3}
$$

Where $\mathrm{Y}_{\text {lipase }}$ is the response (lipase production) and $X_{1}$, $X_{2}$ and $X_{3}$ are the coded values of the test variables (waste frying oil, triton X-100 and $\mathrm{MnSO}_{4}$ ) respectively. The threedimensional response surface plots are the graphical representations of the regression equation. They are helpful in understanding both the main and the interaction effects of the

\begin{tabular}{|c|c|c|c|c|c|c|c|c|}
\hline \multicolumn{9}{|c|}{ Factor levels } \\
\hline & \multicolumn{2}{|c|}{$\begin{array}{c}\text { Waste frying oil } \\
\left(X_{I}\right)\end{array}$} & \multicolumn{2}{|c|}{$\begin{array}{c}\text { Triton } \\
\mathbf{x 1 0 0}\left(X_{2}\right) \\
\end{array}$} & \multicolumn{2}{|c|}{$\begin{array}{c}\mathrm{MnSO}_{4} \\
\left(X_{3}\right) \\
\end{array}$} & \multicolumn{2}{|c|}{$\begin{array}{c}\text { Lipase activity } \\
\text { (U/ml ) }\end{array}$} \\
\hline 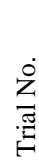 & $\frac{0}{0}$ & 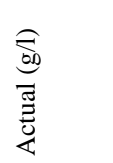 & $\frac{0}{0}$ & 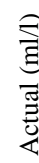 & $\begin{array}{l}\overline{0} \\
0 \\
0\end{array}$ & 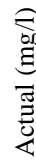 & 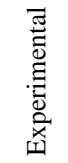 & 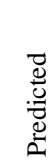 \\
\hline 1 & -1 & 60 & -1 & 1 & 0 & 2 & 420 & 392 \\
\hline 2 & +1 & 100 & -1 & 1 & 0 & 2 & 350 & 310 \\
\hline 3 & -1 & 60 & +1 & 4 & 0 & 2 & 170 & 190 \\
\hline 4 & +1 & 100 & +1 & 4 & 0 & 2 & 210 & 238 \\
\hline 5 & 0 & 80 & 0 & 2 & -1 & 1 & 250 & 236 \\
\hline 6 & -1 & 60 & 0 & 2 & -1 & 1 & 140 & 166 \\
\hline 7 & +1 & 100 & 0 & 2 & +1 & 4 & 50.0 & 34.0 \\
\hline 8 & -1 & 60 & 0 & 2 & +1 & 4 & 160 & 142 \\
\hline 9 & +1 & 100 & -1 & 1 & -1 & 1 & 180 & 210 \\
\hline 10 & 0 & 80 & -1 & 1 & +1 & 4 & 210 & 250 \\
\hline 11 & 0 & 80 & +1 & 4 & -1 & 1 & 230 & 190 \\
\hline 12 & 0 & 80 & +1 & 4 & +1 & 4 & 70.0 & 64.0 \\
\hline 13 & 0 & 80 & 0 & 2 & 0 & 2 & 340 & 344 \\
\hline 14 & 0 & 80 & 0 & 2 & 0 & 2 & 334 & 344 \\
\hline 15 & 0 & 80 & 0 & 2 & 0 & 2 & 338 & 344 \\
\hline
\end{tabular}
factors on the response value.
Table 2: Experimental results of Box-Behnken design for lipase activity by Bacillus cereus ASSCRC-P1.

Table 3: Statistical analysis of Plackett- Burman design showing coefficient values, $t$-test and $P$-values for each variable on lipase activity.

\begin{tabular}{ccccc}
\hline Variables & Coefficient & $\boldsymbol{t}$-test & P-value & $\begin{array}{c}\text { Confidence } \\
\text { level \% }\end{array}$ \\
\hline Intercept & 93.488 & & & \\
Culture volume & 23.155 & 2.60 & 0.0100 & 99 \\
Waste frying oil & 12.808 & 5.12 & 0.0001 & 99 \\
Tween 80 & 25.930 & -1.12 & 0.1387 & 86 \\
Triton X100 & 12.621 & 3.028 & 0.0042 & 99 \\
Peptone & 2.5590 & 1.225 & 0.1196 & 88 \\
Beef extract & -10.325 & 0.754 & 0.2311 & 76 \\
$\mathrm{~K}_{2} \mathrm{HPO}_{4}$ & -16.83 & 1.784 & 0.0473 & 95 \\
$\mathrm{KH}_{2} \mathrm{PO}_{4}$ & -23.087 & 2.747 & 0.0075 & 99 \\
$\mathrm{NaCl}_{\mathrm{KCl}}$ & -19.020 & 1.077 & 0.1492 & 85 \\
$\mathrm{FeSO}_{4}$ & -2.020 & -0.360 & 0.3617 & 63 \\
$\mathrm{ZnSO}_{4}$ & 12.343 & -1.592 & 0.066 & 93 \\
$\mathrm{MgSO}_{4}$ & 15.143 & -0.551 & 0.2945 & 70 \\
$\mathrm{MnSO}_{4}$ & 11.101 & -1.107 & 0.1428 & 85 \\
$\mathrm{CuSO}_{4}$ & 14.449 & 3.607 & 0.0013 & 99 \\
\hline
\end{tabular}

Figure 8(a) showed that the maximum lipase activity was obtained when the concentrations of waste frying oil ranged between $75-95(\mathrm{~g} / \mathrm{l})$ and $1.5-2.5 \mathrm{mg} / \mathrm{ml}$ for Triton X-100. Figure 8 (b) showed that maximum lipase activity was achieved with low concentrations of Triton X-100 and $2-3 \mathrm{mg} / \mathrm{ml}$ of $\mathrm{MnSO}_{4}$ while Figure 8 (c) showed that maximum lipase activity was obtained at the same concentrations of $\mathrm{MnSO}_{4}$ and all levels of waste frying oil. It is also reported that surfactants increase the accessibility of the substrates. However thermostable lipase activity from $G$. stearothermophilus strain-5 was not enhanced by surfactants and lipase activity and could only retain $80 \%$ of its activity after 30 minutes incubation in Triton X-100. In another report, thermoalkaliphilic lipase of Geobacillus sp. T1 was significantly enhanced by Tween 80 (188\%) followed by Tween $60(126 \%)$ but was inhibited by Triton X-100 (72\%) and sodium dodecyl sulfate (SDS) (5\%). Thermostable alkaline lipase from Bacillus sp. DH4 was activated by Triton X-110 and Triton X-114 with $164 \%$ and $148 \%$ activity respectively but was inhibited by SDS (Jagtap et al., 2010). 


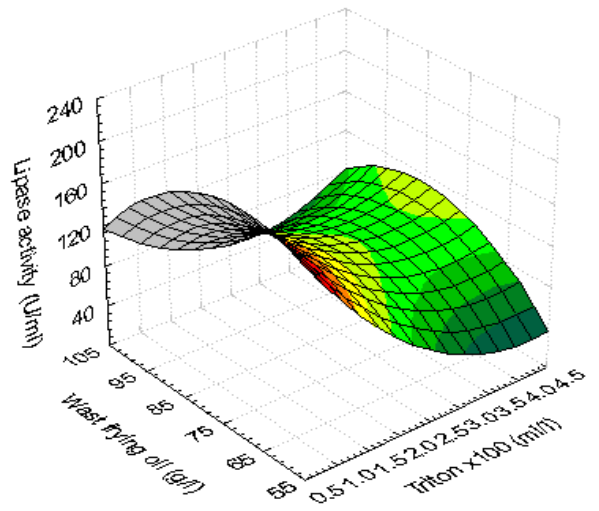

B

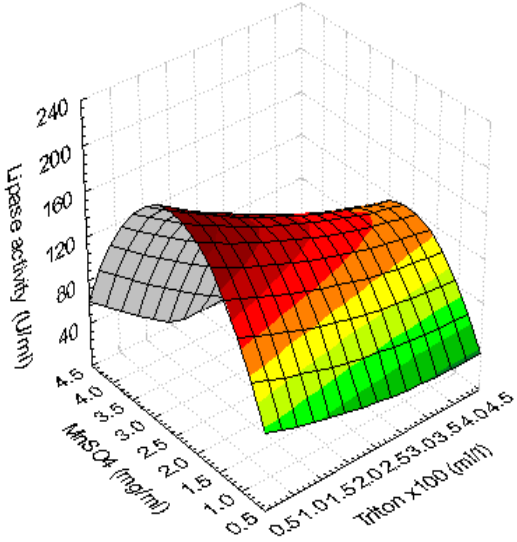

C

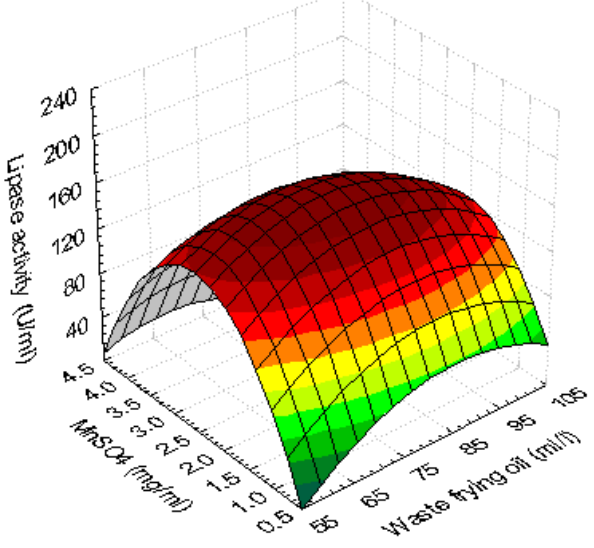

Fig. 8: Response surface plot of lipase production by B. cereus ASSCRCP1 showing: (A) the interactive effects of different concentrations of waste frying oil and triton $\mathrm{X}-100$ at $\mathrm{X}_{3}=0,(\mathbf{B})$ the interactive effects of different concentrations of triton $\mathrm{X}-100$ and $\mathrm{MnSO}_{4}$ at $\mathrm{X}_{1}=0$, (C) the interactive effects of different concentrations of waste frying oil and $\mathrm{MnSO}_{4}$ at $\mathrm{X}_{2}=0$

Table 4: Analysis of variance (ANOVA) test for Box-Behnken experimental design and Model coefficients estimated by multiples linear regression.

\begin{tabular}{ccccc}
\hline Term & $\begin{array}{c}\text { Regression } \\
\text { coefficient }\end{array}$ & $\begin{array}{c}\text { Standard } \\
\text { error }\end{array}$ & t- test & P-value \\
\hline Intercept & -410.548 & 202.685 & -2.026 & 0.089 \\
$\mathrm{X}_{1}$ & 13.479 & 4.696 & 2.87 & 0.028 \\
$\mathrm{X}_{2}$ & -109.823 & 44.68 & -2.458 & 0.049 \\
$\mathrm{X}_{3}$ & 187492.2 & 41773.412 & 4.488 & 0.004 \\
$\mathrm{X}_{1}{ }^{2}$ & -0.09 & 0.029 & -3.114 & 0.021 \\
$\mathrm{X}_{2}{ }^{2}$ & 7.911 & 6.204 & 1.275 & 0.249 \\
$\mathrm{X}_{3}{ }^{2}$ & $-3.39 \mathrm{E}+07$ & $5.71 \mathrm{E}+06$ & -5.929 & 0.001 \\
$\mathrm{X}_{1} \mathrm{X}_{2}$ & 0.576 & 0.332 & 1.737 & 0.133 \\
$\mathrm{X}_{1} \mathrm{X}_{3}$ & -400.77 & 359.391 & -1.115 & 0.307 \\
$\mathrm{X}_{2} \mathrm{X}_{3}$ & -410.548 & 202.685 & -2.026 & 0.089 \\
\hline
\end{tabular}

$\mathrm{F}$ value $=10.495 ; \mathrm{P}>\mathrm{F}=0.005 ; \mathrm{R}^{2}=0.933 ; \mathrm{R}=0.966 ;$ Adjusted $\mathrm{R}^{2}=0.844$.
The results obtained by (ANOVA) analysis (Table 4) showed a significant $F$-value (10.495) which implied the model to be significant. Model terms have values of Prob > F (0.0001) less than 0.05 , considered significant. The determination of coefficient $\left(\mathrm{R}^{2}\right)$ was calculated as 0.933 for lipase activity (a value of $R^{2}>0.75$ indicated the aptness of the model) which indicates the statistical model can explain $93.3 \%$ of variability in the response.

The goodness of the model can be checked by the determination of coefficient $\left(R^{2}\right)$ and correlation coefficient $(R)$. The $R^{2}$ value is always between 0 and 1 . The closer $R^{2}$ value to 1 , the stronger the model and the better in the predicted response. The value of $R$ (0.966) for (Eq. 6) being close to 1 indicated a close agreement between the experimental results and the theoretical values predicted by the model equation. An overall 2.15-fold increase in lipase was being achieved after application of RSM. This fold increase obtained from our results is more than that obtained by Staphylococcus arlettae JPBW-1 through optimization of fermentation variables using response surface methodology recorded 1.8-fold in lipase production as reported by Chauhan et al. (2013). In another report, a 1.6-fold increase in lipase production observed in Arthrobacter sp. BGCC\#490 followed by a 1.4-fold increase by Enterobacter aerogenes under optimized conditions of physico-chemical parameters using statistical methods . On the other hand, our fold increase is less than 3.15 and a 5-fold obtained by Enterococcus faecium MTCC 5695 and Burkholderia sp. respectively using RSM optimization (Ramakrishnan et al., 2013).This reflects the necessity and value of optimization process.

\section{Validation of the model}

Three repeated experiments were performed under the predicted optimum medium (g/l): waste frying oil, $80 ; \mathrm{KH}_{2} \mathrm{PO}_{4}$, 2; $\mathrm{K}_{2} \mathrm{HPO}_{4}, 2$; peptone, 5; beef extract, 5; $\mathrm{CuSO}_{4}, 0.001 ; \mathrm{NaCl}$, $0.5 ; \mathrm{MnSO}_{4}, 0.002$ with addition of $2 \mathrm{ml} / \mathrm{l}$ of triton X-100 and culture volume, $50 \mathrm{ml}$. Under these conditions, lipase activity was $340 \mathrm{U} / \mathrm{ml}$ which was in close agreement with the predicted (344 U/ml).

Therefore, these models could be considered as quite reliable for predicting the lipase production from Bacillus cereus ASSCRCP1. Therefore, optimization through statistical experimental design has been applied in the production of many lipolytic enzymes (Kock et al., 1996).

\section{CONCLUSION}

In this report we studied the production of thermostable lipase from Bacillus cereus ASSCRC-P1 isolated from soil contaminated with oil beside the oil wells in El Ain El Sokhna, Egypt characterized with hot weather. The optimization of the enzyme production by using statistical experimental design was done by using waste frying oil based medium. A highly significant quadratic polynomial equation obtained by the Box-behnken design was very useful for determining the optimal concentrations of constituents that have significant effects on lipase production. A high similarity was observed between the predicted and experimental results, which reflected 
the accuracy and applicability of RSM to optimize the process for lipase production.

\section{ACKNOWLEDGEMENT}

This work was supported by National Research Center, Chemistry of Natural and Microbial Products Department, Pharmaceutical Industries Division, National Research Center (Egypt).

\section{REFERENCES}

Abdel-Fattah YR, Gaballa AA. Identification and overexpression of a thermostable lipase from Geobacillus thermoleovorans Toshki in Escherichia coli, Microbiol Res 2008; 163: 13-20.

Akhmaloka SA, Nurbaiti S, Tika IN, Warganegara FM. Ribotyping Identification of Thermophilic Bacterium from Papandayan Crater. Proceedings ITB on Engin Sci. 2006; 38:1-10.

Akhtar MW, Mirza AQ, Chughtai MID. Lipase induction in Mucor hiemalis. Appl Environ. Microbiol 1980; 40: 257-263.

Aravindan R, Anbumathi P, Viruthagiri T. Lipase applications in food industry. Ind J of Biotec 2007; 6: 141-158

Boonmahome P, Mongkolthanaruk, W. Lipase-Producing Bacterium and its Enzyme Characterization. J Life Sci and Technol. 2013; 1:196-200.

Box GEP, Behnken DW. Some new three level designs for the study of quantitative variables. Technometrics. 1960: 2:455-475.

Brodsky LI, Ivanov VV, Kalaydzidis YaL, Leontovich AM, Nikolaev VK, Feranchuk SI, Drachev VA. GeneBee-NET: Internetbased server for analyzing biopolymers structure. Biochem 1995; 60: 923-928.

Castro-Ochoa LD, G'omez CR, Alfaro GV. Screening, purification and characterization of the thermoalkalophilic lipase produced by Bacillus thermoleovorans CCR11. Enz and Microb Technol. 2005: 37: 648-654.

Chauhan M, Chauhan RS, Garlapati VK. Modelling and optimization Studies on a novel lipase production by Staphylococcus arlettae through submerged fermentation. Enz Res, 2013; 2013: 1-8.

Chien-Hung L, Wei-Bin L, Jo-Shu C. Optimizing lipase production of Burkholderia sp. by response surface methodology. Proc Biochem, 2006; 41:1940-1944.

Clift R. Clean technology: the idea and the practice. J Chem Technol Biot 1997; 68: 347-50.

Dandik L, Arioglu G, Aksoy HA. The enzymatic hydrolysis of used frying oil by native lipase. Appl Biochem Biotech 1993; 42: 119-26.

Dhiman S, Chapadgaonkar SS. Optimization of Lipase Production Medium for Bacterial Isolate. Inter J Chem Technol Res. 2013; 5: 2837-2843.

Edwards U, Rogall T, Blocker H, Emde M, Bottger EC. Isolation and direct complete nucleotide determination of entire genes. Nucleic Acids Res 1989; 17: 7843-785.

Galtier N, Lobry JR. Relationships between genomic G+C content, RNA secondary structures and optimal growth temperature in prokaryotes. J of Mol Evol. 1997; 44: 632-636.

Gowland P, Kernick M, Sundaram TK, Thermophilic bacterial isolates producing lipase. FEMS Microbiol Lett 1987; 48: 339-343.

Guzman MN, de, Vargas VA, Antezana H, Svoboda M. Lipolytic enzyme production by halophilic/halotolerant microorganisms isolated from laguna verde, bolivia. Revista Boliviana de Química. 2008; 25: 14-23.

Haba E, Bresco O, Ferrer C, Marque's A, Busquets M, Manresa A. Isolation of lipase-secreting bacteria by deploying used frying oil as selective substrate. Enzyme Microb Tech 2000; 26: 40-44.

Huge-Jensen B, Galluzzo DR, Jensen RG. Partial purification and characterization of free and immobilized lipases from Mucor miehei. Lipids 1987; 22: 559-565

Jagtap S, Gore S, Yavankar S, Pardesi K, Chopade B. Optimization of medium for lipase production by Acinetobacter haemolyticus from healthy human skin. Indian J Exp Biol 2010; 48: 936-941.

Jensen RG. Detection and determination of lipase (acylglycerolhydrolase) activity from various sources. Lipids 1983; 18: 650-657.

Kazlauskas RJ, Bornscheuer UT. 1998. Biotransformations with lipases, inRehm: HJ, Pihler G, Stadler A, Kelly PJW. (Eds.), Biotechnology, VCH, New York. 37-192.

Kock JLF, Botha A, Bloch J, Nigam S. Used cooking oil: science tackles a potential health hazard. Afr J sci 1996; 92: 513-4.

Kumar D, Parshadb R, Gupta VK. Application of a statistically enhanced, novel, organic solvent stable lipase from Bacillus safensis DVL-43. Intern J Biological Macromol 2014; 66: 97-107.

Kumar S, Kikon K, Upadhyay A, Kanwar SS, Gupta R. Production, purification, and characterization of lipase from thermophilic and alkaliphilic Bacillus coagulans BTS-3. Pro Exp Purif 2005; 41: 38-44.

Lee WM, Kim KJ, Kim MG, Lee SB. Enzymatic resolution of racemic ibuprofen esters: effects of organic solvents and temperature. J Ferment Bioeng 1995; 6: 613-615.

Lin SF, Chiou CM, Tsai YC. Effect of triton X-100 on alkaline lipase production by Pseudomonas pseudoalcaligenes F-111. Biotech Lett 1995; 17: 959

McCutcheon JP, Moran NA. Functional convergence in reduced genomes of bacterial symbionts spanning $200 \mathrm{My}$ of evolution. Genome Biol and Evol. 2010; 2:708-718.

Plackett Rl, Burman JP. The design of optimum multifactorial experiments. Biometrica 1946; 37:305-325.

Ramakrishnan V, Goveas LC, Narayan B, Halami PM. Comparison of Lipase production by Enterococcus faecium MTCC 5695 and Pediococcus acidilactici MTCC 11361 using fish waste as substrate: Optimization of culture conditions by response surface methodology. Int Schol Res Not Biotechnol, 2013; 2013:1-9.

Rubin B, Dennis EA. (Eds.), Lipases: Part B. Enzyme Charaterization and Utilization. Methods in Enzymol 1997; 286:1-563.

Sambrook J, Fritsch EF, Maniatis T. 1989. Molecular cloning A. Laboratory Manual. Cold Spring Harbor Laboratory, NY.

Senthilkumar R, Selvakumar G. A potential lipase producing Bacillus cereus from stored food cereals. Cauvery Res J 2007; 1: 51-55.

Sharma R, Chisti Y, Banerjee UC. Production, Purification, Characterization, and Applications of Lipases. Biotec Adv 2001; 19: 627-662.

Sharma R, Soni S, Vohra R, Gupta L, Gupta J. Purification and characterization of a thermostable alkaline lipase from a new thermophilic Bacillus sp. RSJ-1. Proc. Biochem 2002:37: 1075-1084.

Sunitha I, Subba RMV, Ayyanna C. Optimization of medium constituents and fermentation conditions for the production of Lglutamic acid by the coimmobilized whole cells of Micrococcus glutamicus and Pseudomonas reptilivora. Biopro Eng, 1998; 18: 353 359.

Veerapagu M, Shankara Narayanan A, Ponmurugan K, Jeya KR. Screening selection identification production and optimization of bacterial lipase from oil spilled soil. Asian J Pharm and Clin Res., 2013; 6: $62-67$

Vincze T, Posfai J, Roberts RJ, NEBcutter: a program to cleave DNA with restriction enzymes. Nucleic Acids Res 2003; 31: 3688-3691.

Wang Q, Garrity GM, Tiedje JM, Cole JR. Naive Bayesian Classifier for Rapid Assignment of rRNA Sequences into the New Bacterial Taxonomy. Appl Environ Microb 2007; 73: 5261-5267.

\section{How to cite this article:}

Ghada Awad, Hanan Mostafaa, Enas Danial, Nayera Abdelwahed, Hassan M Awad. Enhanced production of thermostable lipase from Bacillus cereus ASSCRC-P1 in waste frying oil based medium using statistical experimental design. J App Pharm Sci, 2015; 5 (09): 007-015. 